\title{
MOTOR DEVELOPMENT OF BRAZILIAN BREASTFEEDING INFANTS IN SOCIALLY UNFAVORABLE CONDITION OF LIFE
}

\author{
Eduardo Queiroz de Mello', Sophia Motta-Gallo', Flavia Cristina Goulart' ${ }^{1}$ \\ Dafne Herrero' ${ }^{1}$, Paulo Rogerio Gallo ${ }^{1}$
}

\begin{abstract}
The early years of life are of essential importance for child development and growth. The child's development in a social vulnerability and unfavorable life condition can be injured, and that early detection of disorders is fundamental for healthy development. Purpose: To assessment the Alberta Infant Motor Scale as an assessment tool to identify early of disorders in infants until 18 months. Methods: This is an observational, cross-sectional study undertaken in "educational program for the growth and development promotion" at the health unit administered by reference hospital of Health Public System, in Paraisópolis community, São Paulo. The sample $(n=71)$ was composed for infants less than 18 months of age, eutrophic, low biological risk at birth; singleton, full-term births, weight at birth between $2,000 \mathrm{~g} \mathrm{e}^{\prime \prime}$ and $\mathrm{d}^{\prime \prime} 4,500 \mathrm{~g}$ and no associated congenital neurological, cardiac or orthopedic pathologies at the clinical exam. Results: This study presented the greatest prevalence of delay motor neuromotor when compared with the AIMS reference population. First, $8.5 \%$ of the breastfeeding infants are classified as being $m d A$ and $7.0 \%$ are classified as $d m S$ and secondly that, although the category $m d T$ contains $84.5 \%$ of the children, the median of the $z$-score has shifted from the central point of the normal standardized distribution, only $33.7 \%$ of the children, i.e., 24 in 71 , being equal to or above $Z=0(p<0.05)$. Conclusion: The use of AIMS was efficient, practice, low cost and quick applies. Plus a quick view of motor milestone presents by infant. Features that became possible take decision by health team.
\end{abstract}

Key words: neurosensory motor development, breastfeeding infants, assessment tools, AIMS, social vulnerability.

\section{INTRODUCTION}

The early years of life are of essential importance for child development and growth. The infant development depends on genetic trends, maturational and continuous interaction with the environment, not only by point of view physical and but psychosocial also ${ }^{1,2,3}$. The child's development in a social vulnerability and unfavorable life condition can be injured since the first year of life, a period so delicate for cerebral and maturational development. Thus, the follow up is essential for early detection of milestones development disorders 4,5 .

Infant development assessment standardization by means of instruments for this purpose lends added quality to the exams and reduces the subjectivity of the process as also of the taking of decisions ${ }^{1,5}$. The Alberta Infant Motor Scale (AIMS) is a standardized observational assessment tool whose purpose is to assess and to monitor the gross motor development of infants whether born at full-term or premature, from their birth up to 18 months of age, permitting the detection of any existing deviations ${ }^{7}$.

AIMS is an observational measure of infant motor performance which takes into consideration concepts of motor development such as central nervous system maturation, motor dynamic prospects and the assessment of motor development sequence. It is a reference criteria test, with normatized percentage classification which permits to determinate where the individual is situated on an ability measurement or characteristic compared with those of the group of reference ${ }^{7,1}$. Current study with the purpose to compare the original normative data of the Alberta Infant Motor Scale $(n=2202)$ collected 20 years ago with a contemporary sample of Canadian infants has concluded that the sequence and age at emergence of AIMS items has remained similar over 20 years and normative values remain valid 6 .

Infants living by unfavorable conditions of life can show development disorders, including the motor aspect. The conditions of: dwelling,

1 Department of Maternal and Child Health, School of Public Health, University of São Paulo, São Paulo, Brazil. Acknowledgments: Thanks Dr Luiz Carlos de Abreu for suggestions and corrections in the final text version. Corresponding author: sophiamottagallo@usp.br

Suggested citation: de Mello EQ, et al. Motor development of Brazilian breastfeeding infants in socially unfavorable condition of life, Journal of Human Growth and Development, 24(2):163-167

Manuscript submitted Aug 01 2013, accepted for publication Dec 282013. 
income, maternal education, health care access, school access, among others conditions, can have a positive or negative influence on motor development, what could be present in another areas as cognitive and language. This study has a purpose to assessment the Alberta Infant Motor Scale as an assessment tool to identify early of disorders in infants until 18 months.

\section{METHODS}

This is an observational, cross-sectional study undertaken in "educational program for the growth and development promotion" at the health unit clinic administered by reference hospital of Health Public System, in Paraisópolis community, São Paulo (city capital). Situated in one of the richest regions at São Paulo, surrounded by luxurious housing estates and it is undergoing a process of urbanization.

The sample $(n=71)$ was composed for infants less than 18 months of age, eutrophic, low biological risk at birth; singleton, full-term births (above 37 weeks' gestational age), weight at birth between $2,000 \mathrm{~g} \mathrm{e}$ " and $\mathrm{d}^{\prime \prime} 4,500 \mathrm{~g}$ and no associated congenital neurological, cardiac or orthopedic pathologies (exclusion criteria) at the clinical exam. It should be noted that the sample corresponded to about $50 \%$ of the total number of breastfeeding infants less than 18 months of age attended by the health unit during the data collection period.

The researcher assessed all the breastfeeding infants by AIMS at the first occasion and a form for the collection of child and its family socio-demographic information was applied. The qualification of the main researcher to apply the AIMS met all the precision demands during the pre-test recorded on video and analyzed by invited specialists.

The AIMS assesses the breastfeeding child in four different positions and for a preestablished number of motor behaviors: prone -
21 items, supine - 9 items, sitting - 12 items and standing - 16 items. The test has attributed a mark for each item: 0 for a behavior unobserved and 1 for an observed behavior. The maximum possible score for a child is 58 .

The breastfeeding infants performance was classified on the basis of their gross scores, in percentile groups, as A: Atypical Motor Performance ( $m d A$ percentile $d^{\prime \prime} 5$ ); B: Suspect Motor Performance ( $m d S 5<$ percentile $d^{\prime \prime} 10$ ) and $C$ : Typical Motor Performance $(m d T>p 10)$. These may then, according to Piper et al. (1992) ${ }^{8}$ suggestion, be reclassified in percentile normality groups [ $m d T$ ] $10<$ percentile $d^{\prime \prime} 25 ; 25<$ percentile d" 50; $50<$ percentile $d^{\prime \prime} 75 ; 75<$ percentile $d^{\prime \prime} 90$; and percentile $>90$.

Each infant was characterized in accordance with his gross AIMS motor development score. The final sample was composed of $57.7 \%$ male and $42.3 \%$ female infants, aged between 22 days and 17 months. Using the average expected for the age and its respective standard deviation of AIMS $^{7}$, the infants $z$-score was calculated as also their average $z$-score (including the 95\% CI) and the accumulated frequency graph. All the breastfeeding infant with $\mathrm{mdA}$ were referred for treatment at the BHU (Basic Health Unit).

All the infants' mothers, after receiving the necessary guidance, declared themselves, voluntarily, desirous of participating at research project. The study was undertaken after being approved by the Public Health School of the University of São Paulo Research Ethics Committee, in accordance with Resolution 196/ 96 of the National Health Council, protocol no 487.

\section{RESULTS}

This study presented the greatest prevalence of delay motor neuromotor when compared with the AIMS reference population. It may be observed in table 1 that $98.6 \%$ of the mothers had attended the pre-natal course,

Table 1: Distribution of breastfeeding infants by some characteristics

\begin{tabular}{|c|c|c|c|}
\hline Characteristic & Classification & $\mathbf{N}$ & $\%$ \\
\hline \multirow[t]{2}{*}{ Pre-natal ( $\mathrm{n}^{\circ}$ of visits) } & $\begin{array}{l}\text { None } \\
\text { Up to } 6\end{array}$ & $\begin{array}{c}1 \\
35\end{array}$ & $\begin{array}{r}1.4 \\
49.3\end{array}$ \\
\hline & More than 6 & 35 & 49.3 \\
\hline \multirow[t]{3}{*}{ Type of Delivery } & Vaginal & 41 & 57.7 \\
\hline & Cesarean & 22 & 31.0 \\
\hline & Forceps & 8 & 11.3 \\
\hline \multirow[t]{3}{*}{ Age group (months) } & $0-4$ & 20 & 28.2 \\
\hline & $\begin{array}{l}4-8 \\
8-12\end{array}$ & $\begin{array}{l}30 \\
14\end{array}$ & $\begin{array}{l}42.2 \\
19.7\end{array}$ \\
\hline & 12 and + & 7 & 9.9 \\
\hline \multirow[t]{3}{*}{ Birth weight (grams) } & $2.000-2,500$ & 9 & 12.7 \\
\hline & $2.500-3,300$ & 37 & 52.1 \\
\hline & $>3,300$ & 25 & 35.2 \\
\hline \multirow[t]{2}{*}{ Gestational age (weeks) } & $37-40$ & 32 & 45.1 \\
\hline & $40-42$ & 39 & 54.9 \\
\hline \multirow[t]{3}{*}{ Adjustment of Birth Weight by Gestational Age } & PIG & 10 & 14.1 \\
\hline & AIG & 60 & 84.5 \\
\hline & GIG & 1 & 1.4 \\
\hline \multirow[t]{4}{*}{ Breast feeding (days) } & None & 5 & 7.0 \\
\hline & $<120$ & 34 & 47.9 \\
\hline & $120<180$ & 25 & 35.2 \\
\hline & $>180$ & 7 & 9.9 \\
\hline
\end{tabular}


vaginal deliveries predominated and median weight at birth was between 2,500 and 3,300 grams. All the newborn were full-term births and $84 \%$ of them were adequate gestational age. The proportion $(12.7 \%)$ of low weight breastfeeding infants at birth should be noted as also that 10 $(14.1 \%)$ of them were small for gestational age.
Maternal breastfeeding was not continued beyond 120 days for more than half the sample.

As regards the socio-economic conditions of the families, the data confirm the mothers as the main care takers (table 2); young women ( $52 \%$ less than 24 years of age), with a low level of education $(42,2 \%)$. Their dwellings are small

Table 2: Distribution of the breast-feeding infants by social and environmental characteristics

\begin{tabular}{|c|c|c|c|}
\hline Characteristic & Classification & $\mathbf{N}$ & $\%$ \\
\hline Maternal age (years) & $\begin{array}{c}<18 \\
18 \text { to } 24 \\
25 \text { to } 34\end{array}$ & $\begin{array}{l}7 \\
30 \\
29\end{array}$ & $\begin{array}{r}9.9 \\
42.3 \\
40.8\end{array}$ \\
\hline Maternal schooling (years' study) & $\begin{array}{c}35 \text { and over } \\
1 \text { to } 4 \\
5 \text { to } 8 \\
9 \text { to } 11\end{array}$ & $\begin{array}{c}5 \\
30 \\
33 \\
8\end{array}$ & $\begin{array}{l}7.0 \\
42.2 \\
46.5 \\
11.3\end{array}$ \\
\hline Principal care-taker & $\begin{array}{l}\text { Mother } \\
\text { Others }\end{array}$ & $\begin{array}{c}64 \\
7\end{array}$ & $\begin{array}{c}90.1 \\
9.9\end{array}$ \\
\hline Building material of home & $\begin{array}{l}\text { Masonry } \\
\text { Wood }\end{array}$ & $\begin{array}{c}63 \\
8\end{array}$ & $\begin{array}{l}88.7 \\
11.3\end{array}$ \\
\hline Piped water & $\begin{array}{l}\text { Yes } \\
\text { No }\end{array}$ & $\begin{array}{c}70 \\
1\end{array}$ & $\begin{array}{c}98.6 \\
1.4\end{array}$ \\
\hline Electricity & $\begin{array}{l}\text { Yes } \\
\text { No }\end{array}$ & $\begin{array}{c}70 \\
1\end{array}$ & $\begin{array}{c}98.6 \\
1.4\end{array}$ \\
\hline Bathroom & $\begin{array}{l}\text { Own internal } \\
\text { Own external }\end{array}$ & $\begin{array}{c}66 \\
5\end{array}$ & $\begin{array}{l}93.0 \\
7.0\end{array}$ \\
\hline Number of rooms & $\begin{array}{l}1 \text { to } 3 \\
4 \text { or more }\end{array}$ & $\begin{array}{l}54 \\
17\end{array}$ & $\begin{array}{l}76.1 \\
23.9\end{array}$ \\
\hline Number of residents per dwelling & $\begin{array}{c}3 \\
4 \text { to } 6 \\
7 \text { to } 9\end{array}$ & $\begin{array}{l}21 \\
40 \\
10\end{array}$ & $\begin{array}{l}29.6 \\
56.4 \\
14.0\end{array}$ \\
\hline
\end{tabular}

and overcrowded, but provided electricity, piped water and private bathroom. The living conditions of the children and their families, the low level of maternal schooling and the number of residents per dwelling may be taken as life indicators quality. In this context, these variables are understood as determining factors which affect the infants quality of care and show the vulnerability of this age group (breastfeeding infants with $m d A$ ).

It is noteworthy: first, $8.5 \%$ of the breastfeeding infants are classified as being $m d A$ and $7.0 \%$ are classified as $d m S$ and secondly that, although the category $m d T$ contains $84.5 \%$ of the children, the median of the z-score has shifted from the central point of the normal standardized distribution, only $33.7 \%$ of the children, i.e., 24 in 71 , being equal to or above $Z=0(p<0.05)$ (table 3 and graph 1).

Table 3: Distribution of breast-feeding infants assessed by classification of motor development (md).

\begin{tabular}{cccc} 
Alberta Classification & \multicolumn{2}{c}{ Alberta } & $\begin{array}{c}\text { Average } \\
\text { Z score } \\
\text { (dp) }\end{array}$ \\
& $\mathbf{n}$ & $\%$ & \\
mdA* & 6 & 8.5 & $-1.85(0.20)$ \\
mdS* & 5 & 7.0 & $-1.35(0.14)$ \\
mdT* & 60 & 84.5 & $-0.15(0.78)$ \\
Total & 71 & 100.0 & $-0.54(0.90)$
\end{tabular}

mdA- motor development A-atypical; S-suspect; $\mathrm{T}$ - typical
Graph 1: Distribution of breast-feeding infants by accumulated frequency by $z$ score

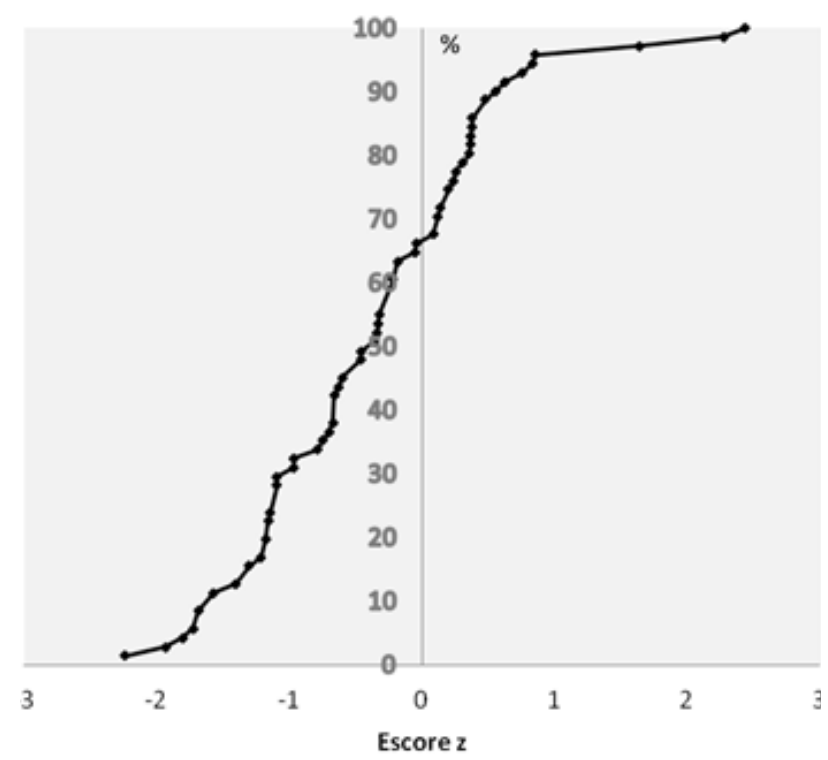

\section{DISCUSSION}

Poverty makes infant's health vulnerable measured and how restricts the emancipatory care takers power, associating other psychosocial difficulties ${ }^{20}$. We take this aspect to be one of the limitations of AIMS. The use of the norm presented by AIMS in other, culturally different, populations with a distinct health profile has been questioned $^{9}$. Questions as gestational age, low weight at birth, geographic localization appear 
also how interference factors about infant development ${ }^{10,11,21}$.

However the authors found that AIMS is a suitable tool for these situations which the infants are exposed. The position that remains for a long time, the prematurity, the low weight, different cultures, habits of each country among others specific characteristics are considered sensible during the assessment by Alberta Infant Motor Scale $9,4,10,11$.

The score obtained in a Dutch study was significantly less than AIMS norm, $17 \%$ being below the 5 th percentile and $29 \%$ than 10 th percentile ${ }^{12}$. $75 \%$ of the Dutch assessed children were below the average score expected for their age, a similar pattern at results of this current study and other Brazilian studies ${ }^{13-15}$. Thus the Brazilian infants, as also the Dutch, presented a standard deviation to the left of the median.

The World Health Organization (2006) ${ }^{16}$ did assessments at five different countries - Ghana, India, Norway, Oman and the United States - with the purpose of establishing standards of infant gross motor development. The outcomes showed differences at the ages of children had reached the six motor milestones assessed (sitting without support, crawling, standing with support, walking with support, standing and walking without support).

The differences among the countries expressed principally the distinct maternity-care patterns influenced by the specific local cultures,

\section{REFERENCES}

1. Herrero D, Goncalves H, Abreu LC. Escalas de desenvolvimento motor em lactentes. Rev Bras Crescimento Desenvolvimento Hum. 2011; 21(1): 122-132

2. Venturella C.B., Zanandrea G., Saccani R., Valentini N.C.. Desenvolvimento motor de crianças entre 0 e 18 meses de idade: Diferenças entre os sexos. Motri. 2013; 9(2): 3-12. DOI: 10.6063/motricidade.9(2).617

3. Spann MN, Bansal R, Rosen TS, Peterson BS. Morphological features of the neonatal brain support development of subsequent cognitive, language, and motor abilities. Hum Brain Mapp. 2014 Feb 25. DOI: 10.1002/ hbm. 22487.

4. Herrero D, Gallo PR, Fujimori M, de Mello Monteiro CB, Valenti VE, Tavares CM, Gallo SM, Macedo CC, Oliveira AG, de Abreu LC ${ }^{1}$. Motor development of infants exposed to maternal human immunodeficiency virus (HIV) but not infected. Int Arch Med. 2013 Oct 31;6(1):45. DOI: 10.1186/1755-7682-6-45.

5. Silva LP, Maia PC, Lopes MM, Cardoso MV. Intraclass reliability of the Alberta Infant Motor Scale in the Brazilian version. Rev Esc Enferm USP. 2013 Oct 47(5):1046-51. DOI: 10.1590/S0080-623420130000500006.

6. Darrah J, Bartlett D, Maguire TO, Avison WR, Lacaze-Masmonteil T. Have infant gross motor abilities changed in 20 years? A re- as well as reflecting a range of normality among healthy populations ${ }^{19}$.

It is possible that disorders in the cut-off points for the age groups may be sufficient to adapt the AIMS for our population, as suggested by the authors of the scale ${ }^{17}$, an initiative also recommended by Lopes et al (2009) ${ }^{18}$.

It should be observed that the choice of the cut-off point will depend on the purpose of each assessor or service: removing more breastfeeding infant's delay suspected (sensitivity) or otherwise (specificity) may harm the demands of the services and/or constrain the links with the care takers, in labeling the children concerned as false positives. This is a discussion that leads us into consideration not only of the costs involved but also of the administrativemanagement priorities definitions at the health services, as also ethical responsibilities required by child care: "primum non nocere" - the principle of the Hippocratic ethic.

The reflection into which these situations lead us, beyond the question of technical or methodological adjustments, relates consequences of the living conditions repercussions and social vulnerability which these children and their families are exposed daily and go beyond the reach of the health professional action.

The use of AIMS was efficient, practice, low cost and quick applies. Plus a quick view of motor milestone presents by infant. Features that became possible take decision by health team.

evaluation of the Alberta Infant Motor Scale normative values. Dev Med Child Neurol. 2014 Mar 29. DOI: 10.1111/ dmcn. 12452.

7. Rocha SR, Dornelasb LF, Magalhães LC. Instrumentos utilizados para avaliação do desenvolvimento de recém-nascidos prétermo no Brasil: revisão da literature. Cad. Ter. Ocup. UFSCar. 2013; 21( 1): 109-117. DOI10.4322/cto.2013.015

8. Piper MC, Pinnel LE, Darrah J, Maguire T, Byrne PJ. Construction and validation of the Alberta Infant Motor Scale (AIMS). Can J Public Health. 1992; 83 Suppl 2: S46-50.

9. Darrah J, Bartlett DJ. Infant rolling abilitiesthe same or different 20 years after the back to sleep campaign? Early Hum Dev. 2013 May 89(5):311-4. DOI: 10.1016/j. earlhumdev. 2012. 10.009 .

10. Van Hus JW, Jeukens-Visser M, Koldewijn K, Van Sonderen L, Kok JH, Nollet F, Van Wassenaer-Leemhuis AG. Comparing two motor assessment tools to evaluate neurobehavioral intervention effects in infants with very low birth weight at 1 year. Phys Ther. 2013 Nov 93(11):1475-83. DOI: 10.2522/ptj. 20120460.

11. Gontijo AP, de Castro Magalhães $L$, Guerra $M Q$. Assessing gross motor development of Brazilian infants. Pediatr Phys Ther. 2014 Spring 26(1):48-55. DOI: 10.1097/PEP. 0000000000000014. 
12. Fleuren KMW, Smit LS, Stijnen T, Hartman A. New reference values for the Alberta Infant Motor Scale need to be established. Acta Pædiatr. 2007; 96(3):424-427. DOI: 10.1111/ j.1651-2227.2007.00111.x

13. Halpern R, Giugliane ERJ, Victora CG, Barros FC, Horta BL. Fatores de risco para suspeita de atraso no desenvolvimento neuropsicomotor aos 12 meses de vida. J Pediatr. 2000; 76(6):421-428. DOI: 00217557/00/76-06/421. 76(6).

14. Halpern R, Barros AJD, Matijasevich A, Santos IS, Victoria CG, Barros FC. Developmental status at age 12 months according to birth weight and Family income: a comparison of two Brazilian birth cohorts. Cad Saude Publica. 2008; 24 Suppl 3: S444-450. DOI: http:// dx.doi.org/ 10.1590/S0102-311X200800 1500010

15. Campos D, Santos DCC, Gonçalves VMG, Goto MMF, Arias AV, Brianeze ACGS, Campos TM, Mello BBA. Concordância entre escalas de triagem e diagnóstico do desenvolvimento motor no sexto mês de vida. J Pediatr. 2006; 82:470-474. DOI: 10.2223/JPED. 1567

16. Who Multicentre Growth Reference Study Group. Assessment of sex differences and heterogeneity in motor milestone attainment among populations in the WHO Multicentre Growth Reference Study. Acta Pædiatr.2006; Suppl 450:66-75. DOI: 10.1080/ 08035320500495530

17. Blanchard Y, Neilan E, Busanich J, Garavuso L, Klimas D. Interrater reliability of early intervention providers scoring the Alberta Infant Motor Scale. Pediat Phys Ther. 2004; 16:13-18.

18. Lopes VB, Lima CD, Tudella E. Neuromotor acquisition rate in Brazilian infants. Inf Child Dev. 2009; 18: 122-132. DOI: 10.1002/icd.595

19. Saccani R, Valentini NC. Analysis of motor development of infants from zero to 18 months of age: representativeness of the motors items of the alberta infant motor scale by age and posture. Journal of Human Growth and Development. 2010; 20 (3).

20. Frônio JS, Coelho AR, Graças LA, Ribeiro LC. Nutritional status and gross motor development of infants between six and eighteen months of age. Journal of Human Growth and Development. 2011; 21 (1).

21. Rodrigues OMPR, Bolsoni-Silva AT. Effects of the prematurity on the development of infants. Journal of Human Growth and Development. 2011; 21 (1). 